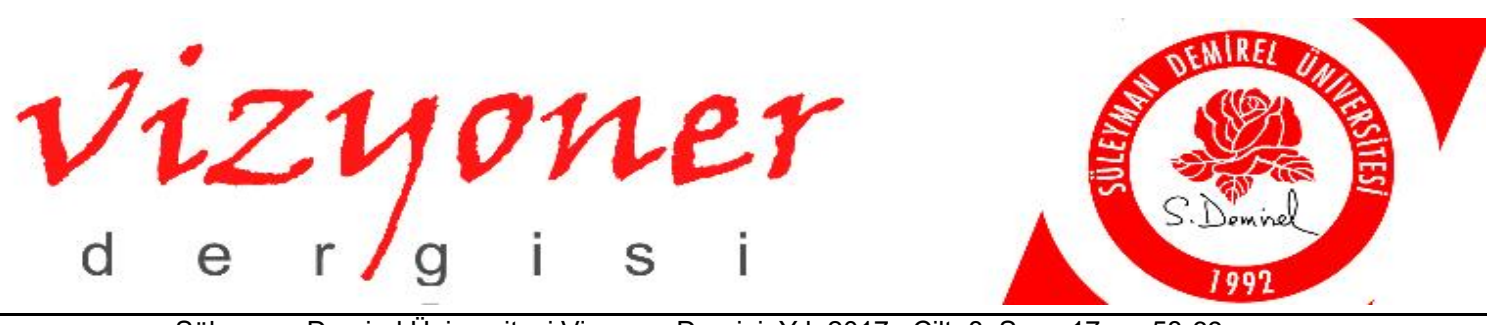

Süleyman Demirel Üniversitesi Vizyoner Dergisi, Yıl: 2017, Cilt: 8, Sayı: 17, ss.58-69. Suleyman Demirel University Visionary Journal, Year: 2017, Volume: 8, Number: 17, pp.58-69.

\title{
İRAN İSLAM CUMHURIYETİ HUKUKUNDA İDARİ YARGI
}

\section{ADMINISTRATIVE LAW JUDICIAL OF THE ISLAMIC REPUBLIC OF IRAN}

\author{
Yrd. Doç. Dr. Nematollah AGHABALAEI FANİ ${ }^{1}$
}

Yrd. Doç. Dr. Emin HÜSEYINOĞLU²

$\ddot{\mathbf{O Z}}$

İran İslam Cumhuriyetinin Anayasası, yargı bağımsızlığı ilkesine esasen, yargı organının toplumda adaleti sağlamakla yükümlü olduğunu vurgulayarak yargı fonksiyonunu, bireylerin kişisel ve sosyal hakların güvencesi olarak tanımlamıştır. İran Anayasası kamu kurumlarının işlem ve eylemlerine karşı "İdari Adalet Divanı" adı altında bir denetim mekanizması öngörmüştür. İdari Adalet Divanı'nın temeli “Şurayı Devlet” olarak Meşrutiyet döneminde (1906-1924) atılsa da bugünkü anlamıyla varlığını ilk defa 1979 İran İslam Devrimi ile ortaya koymuş oldu. Uzun bir geçmişe sahip olan İdari Adalet Divanı bir yargı organı olarak aslında amacına ulaşmış değildir. İran'ın hukuk sistemi, idarenin yargısal denetimini, tam olarak adli yargının dışında, dahası kendine özgü kuralları ve yargılama usulü olarak gerçekleştirememiştir. İran'da idari yargı kuruluşu olarak tek bir mahkeme olan İdari Adalet Divanı bulunmaktadır. İdari Adalet Divanı hem ilk derece mahkemesi, hem de temyiz görevi yapmaktadır. Araştırmamızda genel olarak İran İslam Cumhuriyeti'nin yargı kuruluşları ele alındıktan sonra “İdari Adalet Divanı” adı altında İran'ın idari yargı sistemi açıklanmaya çalışılmaktadır.

Anahtar Kelimeler: İran, İdari Yargı, İdari Adalet Divanı, Anayasa, İslam Cumhuriyeti.

JEL Sinıflandırma Kodları: K23, K33, K41.

\begin{abstract}
The Constitution of the Islamic Republic of Iran has defined the judicial function as assurance of the personal and social rights of the individuals, on the basis of the principle of judicial independence, emphasizing that the judicial body is obliged to provide justice in society. Iran Constitution has envisaged a control mechanism under the name of "Administrative Court of Justice" against acts and actions of public institutions. Even if the basis of Administrative Court of Justice has been laid in the period of Constitutional Monarchy (1906-1924) as "Council of State" it revealed its existence in today's context first time in 1979 with Iran Islamic Revolution. Administrative Court of Justice which has a long history has not reached its objective actually as a judicial body. Iran's legal system failed to perform the judicial review of administration fully outside the judicial justice more as the idiocratical rules and proceeding. There is Administrative Court of Justice in Iran which is the only court as administrative justice institution. The Administrative Court of Justice does the task of court of first instance as well as appeal. In our research generally after discussing the judicial institutions of Islamic Republic of Iran the administrative judicial system of Iran is tried to be explained under the name of Administrative Court of Justice.
\end{abstract}

Keywords: Iran, Administrative Judicial, Administrative Court of Justice, Constitution, Islamic Republic.

JEL Classification Codes: K23, K33, K41.

\footnotetext{
Mehmet Akif Ersoy Üniversitesi, İktisadi ve İdari Bilimler Fakültesi, Kamu Yönetimi Bölümü, nfanid@mehmetakif.edu.tr

Karabük Üniversitesi, İktisadi ve İdari Bilimler Fakültesi, Siyaset Bilimi ve Kamu Yönetimi Bölümü, eminhuseyinoglu@karabuk.edu.tr
} 


\section{GİRIŞ}

Gözü kapalı Themis elindeki terazi ile adaleti doğru biçimdeki tartıyor olmasaydı, belki elinden değirmenini almaya kalkan krala karşı ihtiyar değirmenci, "Berlin'de hakimler var" sözünü söylemeye cesaret edemezdi. Hakimlerin özgürce ve herhangi bir dış baskıya maruz kalmadan kararlarını verebilmesi anlamındaki yargı bağımsızlığı ilkesinin ortaya çıkışı 17. yüzyılda Aydınlanma ve rasyonel hukuk çerçevesinde biçimlenmeye başlamış, 18. ve 19. yüzyıllardaki Fransız Devrimi ya da Amerika'daki anayasacılık hareketleriyle de anayasal belgelere girmiş̧tir.

Hukuk devleti, demokratik sistemlerin vazgeçilmez unsurlarından biri olarak kabul edilmektedir. Yarg1 bağımsızlığı ise hukuk devletinin olmazsa olmazları arasında yer almaktadır. Yargı organını hukuk devleti açısından ele aldığımızda, bu organın siyasi iktidara karşı bağımsız olması gerektiği kaçınılmazdır. Yargı organın amacı, halkın iradesinden kaynaklanan hukuk düzeninin korunması ve adaletin sağlanmasıdır. $\mathrm{Bu}$ bağlamda yargı fonksiyonu dolayısıyla mahkemeler, bireylerin sosyal statüsüne bakmaksızın eşitlik ilkesine esasen onlar arasındaki ve daha da önemlisi kamu kurumları ile ilgili uyuşmazlıkları hukuk normları çerçevesinde çözmekle yükümlüdür. Özetle hukuk devleti, devletin tüm işlem ve eylemlerinin yargı tarafindan denetlenmesi demektir.

"Yargı birliği sistemi" olarak adlandırılan ve Aglo-Sakson ülkelerde uygulanan sistemde, idari eylem ve işlemlerden kaynaklanan uyuşmazlıklar adliye mahkemeleri tarafindan çözümlenmektedir. Bu sistemde idare, hukuk önünde kişilerle eşit statüde kabul edilmektedir (Kalabalık, 2015: 2-3). "İdari yargı sistemi" olarak adlandırılan ve Türkiye gibi Kara Avrupası ülkelerinde uygulanan sistemde ise idarenin yargısal denetimi, adli yargının dışında, kendine özgü kuralları ve yargılama usulü bulunan ayrı bir yargı düzeninde gerçekleşmektedir (Çağlayan, 2015: 40). İdari yargı sistemi, Fransa'da adli yargı mahkemelerine duyulan güvensizlikten doğmuş ve daha sonraları ihtiyaçlara cevap verince diğer ülkelerce de benimsenmiştir (Ergen, 2008: 11). Bu sistem, Fransa'da doğup geliştiği için “Fransız sistemi” olarak da adlandırılmaktadır (Gözler, 2014: 813).

Farklı bir hukuk sistemi olan İslam hukuk sistemi içinde yer alan İran İslam Cumhuriyeti hukukunda da Kara Avrupası hukuk sisteminde olduğu gibi ayrı bir idari yargı sistemi bulunmaktadır.

İran İslam Cumhuriyeti Anayasası, yargı bağımsızlığı ilkesine esasen, yargı organının toplumda adaleti sağlamakla yükümlü olduğunu vurgulayarak yarg1 fonksiyonunu, "bireylerin kişisel ve sosyal haklarının güvencesi" olarak tanımlamıştır. Anayasanın 173. maddesine göre, "Bireylerin devlet ve diğer kamu kurum ve kuruluşların işlem ve eylemlerine karşı itiraz ve şikayetleri incelemek amacıyla, Yargı Organı Başkanı'nın denetimi altında İdari Adalet Mahkemesi adı altında bir mahkeme kurulacaktır. Bu mahkemenin görevi, yetkileri ve çalışma şekli kanun tarafindan belirlenecektir". İran'da kamu kurum ve kuruluşlarının işlem ve eylemlerine karşı "İdari Adalet Divanı” adı altında bir denetim mekanizması öngörülmüştür.

Araştırmamız iki bölümden oluşmaktadır. Birinci bölümde, ana hatlarıyla İran'ın yargı örgütü konusu incelenmektedir. İkinci bölümde ise, İdari Adalet Divanı çerçevesinde İran'ın idari yargı sistemi incelenmektedir.

\section{2. İRAN İSLAM CUMHURIYETİ YARGI ÖRGÜTÜ}

\subsection{Yargı Organı Başkanı (Reis-e Kuvveye Kazaiyye)}

İran İslam Cumhuriyeti yargısında, Yargı Organı Başkanı önemli yer tutmaktadır. İfade etmek gerekir ki, Türk hukuk sisteminde buna benzer bir kurum bulunmamaktadır.

Yargı organına ait yargısal, idari ve icrai tüm görevleri yerine getirmek için adil ve yargı konularına hakim bir müçtehit, Lider (Devlet Başkanı) tarafından beş yıllık süre için Yargı Organı Başkanı olarak atanır CÜMLE BOZUK. Yargı Organı Başkanı, yargının en yüksek makamıdır (AY. ${ }^{3}$ m.15). İran Anayasası'na göre, Yargı Organı Başkanı'nın görev yetkileri aşağıdakilerden oluşmaktadır:

a) İslam Cumhuriyeti'ne uygun yargı konuları ile ilgili yasa tasarıları hazırlamak (AY. m.158/1),

b) Anayasanın 157. maddesine esasen adli kuruluşları idari ve yargısal açıdan örgütlemek (AY. m.158/2),

\footnotetext{
İran İslam Cumhuriyeti’nin Anayasası
} 
c) Adil ve liyakatli hakimlerin atanması ve tayin, nakletme, derece ilerlemesi gibi diğer özlük işlerini yerine getirmek (AY. m.158/2),

d) Cumhurbaşkanı'nın atayacağı Adalet Bakanı'nı Cumhurbaşkanı'na önermek (AY. m.160/1),

e) İslami Şura Meclisi tarafından hazırlanan bütçe ile ilgili yargı organında ita amiri olarak görevi yapmak (AY. m.160/2),

f) İçtihatları birleştirme kararları ile ilgili olarak Yüce Divan'ı toplantıya çağırmak (AY. m.161/),

g) Yüce Divan Başkanı ve Devlet Genel Savcısı'nı atamak (AY. m.162),

h) Divani Muhasebat ve İdari Adalet Divanı'nı denetlemek (AY. m.173, m.174).

\subsection{Genel Görevli İlk Derece Mahkemeleri (Hukuk ve Ceza Mahkemeleri)}

Genel görevli ilk derece mahkemeleri hukuk ve ceza mahkemelerinden oluşmaktadır. Ceza mahkemeleri dava önemine göre birinci ve ikinci derece olmak üzere ikiye ayrılmaktadır (HCDK. ${ }^{4}$ m.7). İdam, recim, kısas, müebbet hapis cezasını gerektiren suçlar ile siyasi suçlar ve basın suçları birinci derece ceza mahkemelerinde görülür. Diğer ceza davalarına ise ikinci derece mahkemelerinde bakılır (İCMK. ${ }^{5} \mathrm{~m} .302$ ). Eskiden il merkezlerinde bulunan ve istinaf niteliğinde olan il mahkemeleri, ceza mahkemelerinin kararlarına karşı itirazları incelemekle görevliydi. Fakat 14.7.2016 tarihinde İran Ceza Muhakemeleri Usulü Kanunu'nda yapılan değişiklikle il mahkemeleri kaldırılmıştır. Yeni düzenlemeye göre, il merkezlerinde kurulan birinci derece ceza mahkemelerinin görevi yukarıda saydığımız davalara ilk derece mahkemesi olarak bakmak ve ikinci derece ceza mahkemelerinin nihai kararlarını itiraz mercii olarak incelemektir (İCMK. m. 296). Birinci derece ceza mahkemelerinin itiraz mercii olarak verdiği kararları kesindir ve bunlara karşı başka bir mercie başvurulamaz (İCMK. m.426) . Birinci derece ceza mahkemelerinin yukarıda belirtilen davalarda ilk derece mahkemesi verdiği nihai kararlara karşı ise Yüce Divan’a temyiz başvurusu yapılabilir (İCMK. m. 427).

İran'da hukuki uyuşmazlıklar hukuk mahkemelerinde görülmektedir. Ceza mahkemelerinde bulunan "birinci ve ikinci derece" ayrımı hukuk mahkemelerinde bulunmamaktadır. Eskiden hukuk mahkemeleri de birinci ve ikinci derece mahkemeler olarak ikiye ayrılmaktaydı. Fakat 2016 yılında yapılan değişikle bu ayırıma son verilmiştir.

Hukuk ve ceza mahkemesi hakimleri kararlarını kanun, şeriat ve içtihatlara esasen vermekle yükümlüdürler (HCDK. m.9). Hukuk ve ceza mahkemelerin kurulması ve kaldırılması, Yargı Organı Başkanı'nın görev ve yetkileri arasında yer alır (HCDK. m.2).

Düzenin Yararını Teşhis Kurulu ${ }^{6}$, Anayasayı Koruyucu Konsey ${ }^{7}$ üyeleri, milletvekilleri, bakanlar ve yardımcıları gibi üst düzey kamu görevlilerin bütün suçları ile yargılama yetkisi başkent Tahran il merkezindeki ceza mahkemelerine aittir (HCDK. m.2).

\subsection{Genel Görevli Adli Savcılık}

Genel Görevli Adli Savcılık; suç haberinin ortaya çıktığı andan itibaren sanık veya sanıkların takibi, suçla ilgili delilleri toplayarak Devlet ve Din adına (İslam Dininin gerekleri) araştırma ve soruşturma faaliyetinde bulunmak, koşulların oluşması halinde ceza davasını açmak ve takip etmek, ceza mahkemeleri tarafından verilen kararları yerine getirmekle görevli bir yargı kuruluşudur (HCDK. m.2).

Genel Görevli Adli Savcılık; Devlet Genel Başsavcısı (Dadsetan Kolle Keşver) ${ }^{8}$, her il merkezinde bulunan başsavcı, savcılar, savcı yardımcıları, dedektifler (bazpors), sorgu savcıları ve infaz savcılarından oluşmaktadır.

4 Hukuk ve Ceza Mahkemeleri ile Devrim Mahkemelerin Kuruluşu Hakkında Kanun

İran Ceza Muhakemeleri Usul Kanunu

6 Düzenin Yararını Teşhis Kurulu (Mecma-i Teşhis-i Maslahat), Parlamento ile Anayasayı Koruyucu Konsey arasındaki uyuşmazlıkların nihai çözüm merciidir.

7 İran Anayasası'nda, yasaların Anayasaya uygunluk denetimi için bir anayasa yargısı öngörülmemiştir. Fakat anayasa yargısı yerine Anayasayı Koruyucu Konsey (Şuraye Nigehban-e Kanun-e Esasi) bir öndenetim mekanizması öngörülmüştür. Buna göre, parlamentodan çıkan bir kanun yürürlüğe girmeden önce Anayasayı Koruyucu Konsey'in onayına sunulur. Konsey ilgili kanunu anayasaya ve dini ilkelere aykırı bulursa, tekrar görüşülmesi için parlamentoya iade eder. Parlamento'nun 1srar etmesi halinde bu konuda son kararı Düzenin Yararını Teşhis Kurulu verir (Bu konuda bkz. AY. m.72, m.91, m.94, m.96).

8 Devlet Genel Başsavcısı, Türk hukukundaki Yargıtay Cumhuriyet Başsavcısı'na benzemektedir. 
Genel Görevli Adli Savcılık’ta, savcıdan sonra en yüksek mercii olarak dedektifler yer almaktadır. İdam, kısas, diyet, müebbet hapis cezasını gerektiren suçlar ve siyasi suçlarla ilgili cezai takiplerin ve suç soruşturmasının başlatılması ve yürütülmesi dedektifin görev ve yetkileri arasında yer alır (İCMK. m.92, m.302). Fakat iş hacminden dolayı veya dedektifin yokluğunda bu görevleri bizzat savcı kendisi yürütmekle sorumludur (İCMK. m.92). Birinci derece ceza mahkemelerinin duruşmalarında iddianame ile ilgili sunum ve savunmaları dedektif şahsen yapar. Dedektifler, savcıya karşı muhalefet şerhi koyma yetkisine de sahiptirler. Savcı ile dedektif arasındaki uyuşmazlıkların çözüm mercii ise ceza mahkemeleri hakimidir (İCMK. m.89).

Savcı Yardımcıları; savcının emri ile kamu davasını açma, dedektif ve sorgu savcısını denetleme, dedektif ve sorgu savcısının kararları hakkında düşüncesini bildirme ve savcılık teşkilatındaki idari işleri yürütmekle görevlidirler (İCMK. m.88).

Sorgu savcısı ise savcının emri altında görev yapakta olup, savc1 tarafindan görevlendirilen konularda aynen onun gibi yetkilere sahip olmaktadır (İCMK. m.88). İkinci derece ceza mahkemelerinin duruşmalarında, iddianamenin savunması savcı veya onun görevlendireceği savcı yardımcısı veya sorgu savcısı tarafından yapılır (İCMK. m.300).

Sorgu savcıları da detektifler gibi kamu davası açmak, sorgulama, soruşturma ve cezai takipleri yürütmekle görevlidir. Ancak detektiften farklı olarak, sorgu savcısının tüm kararları savcının onayına sunulur. Savcı ile sorgu savcısı arasında karar uyuşmazlıklarında savcının kararı esas alınır. (İCMK. m.3). Buna karşılık savcı ve dedektif arasındaki uyuşmazlıklar kural olarak hakim tarafından çözülür. Ayrıca soruşturmanın ilk evresinde görevli makam dedektiftir. Özetle; birinci derece ceza mahkemelerinin görev alanına giren idam, kısas, diyet, müebbet hapis cezasını gerektiren suçlar ve siyasi suçlarla ilgili cezai takiplerin ve suç soruşturmasının başlatılması ve yürütülmesi dedektifin görev ve yetkileri arasında yer alır. İkinci derece ceza mahkemelerinin suçları ile ilgili soruşturmaları yürütmek ve cezai takibatı başlatmak ise sorgu savcısının görev alanına girer (Zebihi, 2016).

\subsection{Yüce Divan (Divan-i Aliye-ye Keșvar)}

\subsubsection{Yüce Divan'ın Tarihçesi}

Yüce Divan'ın kuruluş tarihi 1907 tarihli İran Meşrutiyet Anayasası'na dayanmaktadır. İran Meşrutiyet Anayasası'nın 85. maddesine göre, “Tüm ülkedeki uyuşmazlıklarla ilgili bir tek başkent Tahran'da 'Temyiz Divanı' (Divanhane-ye Temyiz) adl altında bir temyiz mercii kurulacaktır. Bu merci, Bakanlıklarla ilgili uyuşmazlıklar hariç katiyen hiçbir davaya ilk derece mahkemesi olarak bakamaz”. Aslında Meşrutiyet Anayasası'nın 85. maddesinde öngörülen Yüce Divan, Fransız Devriminin hemen ardından 1791 yılında Anayasada yer alan Yüksek Temyiz Divanı’nın hemen hemen aynısı sayılır. Meşrutiyet döneminden sonra, Pehlevi Krallığı döneminde Milli Meclis (parlamento) tarafından 1939 yılında çıkarılan Yargısal Kuruluşlar Hakkında Kanun ile Temyiz Divanı'nın görev ve yetkileri bazı değişikliklere uğramış ve ismi "Devlet Divanı” olarak değiştirilmiştir.

1978 Devriminden sonra en önemli hukuki yeniliklerinden birisi Yüce Divan'ın (Divan Aliye-ye Devlet) 1978 Anayasasında yer almasıdır. 1978 Anayasası'nın 161. ve 162. maddeleri, Yüce Divan'la ilgili hükümlere yer vermiştir ${ }^{9}$

\subsubsection{Yüce Divan'ın Oluşumu}

Yüce Divan; başkanla birlikte, hukuk ve ceza olmak üzere iki bölüm ve bir de Büyük Genel Kurul'dan (İçtihadı Birleştirme Kurulu) oluşur. Ayrıca Yüce Divan’a bağlı Devlet Genel Başsavcılığı (Dadsetan-e Kolle Keshvar) da bulunmaktadır. Halihazırda Yüce Divan'da 42 şube bulunmaktadır. Bunlardan sekizi Meşhed ${ }^{10}$ ve Kum kentinde, diğer şubelerin tamamı ise başkent Tahranda görev yapmaktadırlar (CMYDK. m. 36). Şubeler, bir başkan ve bir de tetkik hakimi olmak üzere iki yargıçtan oluşur (CMYDK. m. 38). Ayrıca Yüce Divan

\footnotetext{
9 İran İslam Cumhuriyeti Anayasası'nın 161. maddesine göre, “Yüce Divan; kanunların mahkemeler tarafindan doğru uygulanmasının denetlenmesi, yargısal uyușmazlıklarda içtihatları birleștirmek ve kanunda belirtilen diğer görevleri yerine getirmek üzere Yargı Organı Başkanı tarafindan hazırlanmış olan düzenlemeler çerçevesinde kurulur". Anayasanın 162. maddesine göre ise, "Yüce Divan Başkanı ve Devlet Genel Başsavcısı adil müçtehit ve adli konulara hakim kişiler olarak 5 yıllık dönem için Yüce Divan yargıçlıların önerisi üzere Yargı Organı Başkanı tarafindan atanırlar”.

10 Meşhed, Horasan vilayetinin merkezidir. Yüce Divan şubelerine, nüfus açısından başkent Tahran'dan sonra İran'ın en büyük kentleri olan Tebriz ve İsfahan gibi büyükşehirlerde değil de sadece Kum ve Meşhed gibi iki dini kentte ihtiyaç duyulması ilginçtir.
} 
Başkanı'nın kararıyla her șubede bir başkan yardımcısı da bulunabilir. Fakat karar verme yetkisi başkan ve tetkik hakimine aittir (CMYDK. ${ }^{11}$ m. 37). İran Yüce Divan'1, Türk hukukundaki Yargıtay'la aynı hukuki niteliktedir.

\subsubsection{Yüce Divanın Görev ve Yetkileri}

Anayasa ve ilgili kanunlara esasen, Yüce Divan’ın başlıca görevlerini şu şekilde sıralanabilir:

a) Yüce Divan, yasaların mahkemeler tarafından doğru uygulanmasını sağlamak amacıyla temyiz mercii olarak ilk derece mahkemelerinin bazı kararlarının son inceleme merciidir.

b) Yüce Divan’ın bir diğer görevi içtihadı birleştirme kararı vermektir. Genel görevli adli (hukuk ve ceza mahkemeleri) yargı mercileri ile ihtisas mahkemeleri (Devrim mahkemeleri, İdari Adalet Divanı ve Askeri Yargı) aralarında çıkan hüküm uyuşmazlıklarını nihai olarak çözen mercii Yüce Divan'dır. Bu konudaki Yüce Divan kararları kesin ve bağlayıcı olup, diğer mahkemelerin bunlara aykırı karar vermesi mümkün değildir (Hachemi, 2004: 418).

c) Genel görevli adli (hukuk ve ceza mahkemeleri) yargı mercileri ile ihtisas mahkemeleri arasındaki görev uyuşmazlıklarını Yüce Divan çözer. İdari Adalet Divanı ile genel görevli adli merciler (hukuk ve ceza mahkemeleri ) arasındaki görev uyuşmazlıklarını da Yüce Divan çözer (ADYUK. ${ }^{12}$ m.270).

d) Cumhurbaşkanı'nı göreviyle ilgili işlediği suçlardan dolayı yargılamak yetkisi de Yüce Divan'a aittir. İran Anayasası'nın 110/10. maddesine göre, Devlet Başkanı sıfatıyla Lider'in görev ve yetkilerinden biri de Cumhurbaşkanı'nı görevden almaktır. Ancak Lider'in bu yetkisini kullanabilmesi için öncelikle Yüce Divan'ın Cumhurbaşkanını suçlu bulmuş olması gerekir.

\section{5. İhtisas Mahkemeleri}

\subsubsection{Askeri Yargı Teşkilatı (Sazman-i Ghazai Niroohay-e Mosallah)}

İran askeri yargı teşkilatı, yargı organının bir parçası olarak anayasada öngörülen tek ihtisas yargı kuruluşudur. Anayasanın 172. maddesine göre, "Milli ordu, devrim muhafizlarl ordusu, jandarma, polis mensuplarının askeri ve güvenlik görevleriyle ilgili suçların soruşturulması ve kovuşturulması için askeri mahkemeler kurulacaktır. Fakat bunların adi suçlart ile ilgili görevli mahkeme, genel görevli mahkemeler olarak adli yargıda çözümlenecektir. Askeri savcllık ve askeri mahkemeler, yargl organına bağlı kuruluşlar olarak adli yargl usul ve esaslarina tabidir".

Askeri mahkemeler, birinci ve ikinci derece askeri mahkemeler olmak üzere ikiye ayrılır. Olağanüstü durumlarda bu mahkemeler, birinci ve ikinci derece askeri harp mahkemeleri olarak görev yaparlar (AYUM. m.582). Askeri mahkemelerin görevleri bakımından genel görevli adli ceza mahkemelerindeki hükümler uygulanır (AYUM. m.583). Dolayısıyla idam, kısas, recim, müebbet hapis cezalarını gerektiren suçlar ve siyasi suçlar gibi önemli askeri ceza davalarında görevli mahkeme birinci derece askeri mahkemelerdir. Asker ve polis kişilerin görevleri ile ilgili diğer suçlara ilişkin askeri ceza davaları ise ikinci derece askeri mahkemelerde görülür. İkinci derece askeri ceza mahkemelerinin kararlarına karşı birinci derece askeri ceza mahkemelerine itiraz edilebilir. Birinci derece askeri mahkemelerde, ilk derece olarak görülecek davaların temyiz mercii Yüce Divan'dır. Soruşturma evresi askeri savcılık tarafından, kovuşturma evresi ise görevli mahkeme olan birinci veya ikinci derece askeri mahkeme tarafından yürütülür.

Askeri Yargı Teşkilatı Başkanı, Yargı Organı Başkanı tarafından atanır. Askeri Yargı Teşkilatı Başkanı'nın önerisi ve Yargı Organı Başkanı'nın kararıyla il merkezlerinde iş hacmine göre ikinci derece askeri mahkemeler ve askeri savc1lık kurulabilir (AYUK. $\left.{ }^{13} \mathrm{~m} .634 ; \mathrm{m} .635\right)$.

\subsubsection{Yargıçların Disiplin Mahkemeleri (Dadegah-e İntizami-e Gozzat)}

Yargıçların Disiplin Mahkemeleri büyük il merkezlerinde kurulur. Bu mahkemelerin temyiz mercii ise Yüce Divan gibi yüksek mahkeme olarak kabul edilen Yargıçlar Yüksek Disiplin Mahkemesidir. Yargıçlar Yüksek

\footnotetext{
Birinci ve İkinci Derece Ceza Mahkemeleri ve Yüce Divan'ın Kuruluşu Hakkında Kanun

2 Genel Görevli Adli Mahkemeleri ile Devrim Mahkemelerinin Yargılama Usulü Kanunu

13 Askeri Mahkemeler Yargilama Usul Kanunu.
} 
Disiplin Mahkemesi, başkent Tahran'da kurulur. Bu mahkemenin daire sayısı, Yargı Organı Başkanı'nın takdir yetkisine bağlıdır. Her daire bir başkan ve iki üyeden oluşur (YDMK. ${ }^{14}$ m.4).

\subsubsection{Ruhanilerin ${ }^{15}$ İhtisas Mahkemesi (Dadegah-e Vijey-e Ruhaniyyat)}

Aslında Ruhanilerin İhtisas Mahkemesi'nin kuruluşu, görev ve yetkileri ile ilgili herhangi bir yasal düzenleme bulunmamaktadır. Sadece İran Hukuk Muhakemeleri Kanunu’nda, Ruhanilerin İhtisas Mahkemesi'nin Devlet Başkanı sıfatıyla Lider tarafindan kuruluşu ile ilgili bir hüküm öngörülmüştür (HMK. ${ }^{16}$ m.528). Bu mahkemenin temeli ilk defa 1979 yılında Devrim Lideri Ayteullah Humeyni'nin fermanı ile atıldı. Bu fermana esasen il merkezlerinde üç kişiden oluşan üst düzey din alimlerinden ve iki kişi de mahallin akil insanlarından oluşan bir heyet ruhanilerin suçları ile ilgili soruşturma başlatıp ve bu konudaki iddianameyi kovuşturmak için devrim mahkemesine sevk edecekti. Ruhanilerin İhtisas Mahkemesi’nin bugünkü yapısı ile göreve başlaması 1988 yılında dönemin Devlet Genel Başsavcısı tarafından hazırlanan ve halen yürürlükte olan "Ruhaniler İhtisas Mahkemesi Savcılı̆̆l ve Muhakeme Usulü" adı altındaki bir yönetmelikle resmen faaliyete geçti (Mohammadi, 2016). Ruhanilerin İhtisas Mahkemesi yargı organı teşkilatı dışında yer alıp, tamamen Devlet Başkanı sıfatıyla Dini Lider'in (Vilayet-e Fakih) denetimine tabidir (RIMY. ${ }^{17}$ m.1). Ruhanilerin İhtisas Mahkemesi'nin merkezi başkent Tahran'dır. Fakat bu mahkemenin diğer illerde de daireleri bulunmaktadır (RİMY. m.9). Ruhanilerin İhtisas Mahkemesi'nin başkanı, birinci daire başkanıdır ve diğer daire başkanları gibi doğrudan doğruya Dini Lider (Vilayet-e Fakih) tarafından atanır (RIMY. m.10, m.50). Birinci daire ayrıca diğer dairelerin nihai kararlarının son inceleme mercidir (RİMY. m.50). Birinci dairenin bu konudaki kararları kesindir (RİMY. m. 49).

Bu mahkemelerin kuruluş felsefesi, “ihtisas mahkemeleri”ne pek uygun değildir. Çünkü bu mahkemelerin görev alanı, din adamlarının sadece görevleri ile işledikleri suçları değil, kişisel suçlarını da kapsamaktadır (RİMY. m. 13).

İran İslam Cumhuriyeti Anayasası, yargılama yetkisini yasama ve yürütmeden bağımsız olan yargı organına vermiştir. Anayasanın 61. maddesine göre, "Yargılama yetkisi, İslami kriterlere esasen (şeriata uygun) genel görevli adli mahkemeler tarafından yürütülür ve kamu yararını gözeterek adaleti sağlamak, davaları görüşmek ve sonuçlandırmak ilahi adalet uygulamakla görevlidir". Yine Anayasanın 156. maddesi, bağımsız yargı organının amacını bireylerin sosyal ve kişisel haklarını korumak ve adaleti sağlamak olarak tanımlamıştır. Ruhanilerin İhtisas Mahkemesi’nin anayasaya aykırı olduğu söylenebilir (Hachemi, 2004: 445).

\subsubsection{Devrim Mahkemeleri}

Günümüz İran'ında bir ihtisas mahkemesi olarak görev yapan devrim mahkemeleri, Fransız Devrimi’nin ardından "terör dönemi" adı verilen 1793-94 tarihlerindeki mahkemelere benzemektedir. Bir açıdan bu mahkemeleri, Türkiye'deki istiklal mahkemelerinin son dönemlerine de benzetebiliriz. Çünkü istiklal mahkemeleri, kuruluş amacından farklı olarak son dönemlerde savaş ve ihtilal gibi özel durumlarda isyancı, bozguncu ve karşı devrimcilerin yargılandığı infaz kurumları niteliğindeydi (Mumcu, 2016). Devrim mahkemeleri, 1970 Devrimi'nin hemen ardından kurulmuştur. Devrimin ilk başlarında göreve başlayan devrim mahkemeleri, meşruiyeti olmasa da mevcudiyetini sürdürmektedir.

1979 Devriminin hemen ardından “Karşı Devrim Suçlarının Yargılamasıyla İlgili Olağanüstü Mahkemeler” adı altına bir kanun, Milli Meclis’te (parlamento) kabul edildi. Bu Kanunun 1. maddesi olağanüstü mahkemeleri, devrim amaçlarına ve milli egemenliğin istikrarına zarar veren devrim karşıtı suçların yargılanması konusunda görevlendirmiştir. 1980 yılında olağanüstü mahkemelerin adı "devrim mahkemeleri” olarak değiştirildi. Bu tarihte Devrim Konseyi’’nin (Şurayı İnkılap) ${ }^{18}$ onayı ile çıkarılan bir tüzükte ilk defa devrim mahkemeleri İran hukuk sistemine dahil edilmiştir" . Nihayet 1983 yılında çıkan "Devrim Mahkemeleri ve Savcılıklarının Görev

14 Yargıçların Disiplin Mahkemesi Kanunu.

15 Ruhaniler, İran'daki din adamlarını ifade etmektedir.

16 Hukuk Mahkemelerinin Kuruluşu Hakkında Kanun.

17 Ruhaniler İhtisas Mahkemesi Savcılı̆̆ ve Muhakeme Usul Yönetmeliği.

181979 İran Devrim, solcu-islamcı koalisyonu olarak başarıya ulaşmıştır. Dolayısıyla Pehlevi monarşisini deviren farklı ideolojilerden oluşan gruplar ve partiler, Devrim Konseyi çatısı altında bir koalisyon hükümeti oluşturdular.

19 Devrim Mahkemeleri ve Savcılıkları Hakkında Tüzük’ün (Ayinname Dadsera ve Dadegahha-ye Enqleb) 2. maddesine göre, “Devrim Mahkemelerin görevleri;

a) Pehlevi Krallı̆̆ lehine devrim karşıtı işlenen suçları, 
ve Yetkileri Hakkında Kanun” ile ardından da 1994 yılında çıkan "Genel Görevli Adli Mahkemeler ve Devrim Mahkemeleri Hakkında Kanun” ile olağanüstü ve dolayısıyla geçici nitelikte olan bu mahkemeler, olağan ve sürekli mahkemeler olarak halen yargılamalara devam etmektedirler.

Devrim Mahkemelerinin meşruiyeti, kuruluş tarihinden günümüze kadar çeşitli muhalif grupları tarafından sorgulanmaktadır. Bu düşünceyi destekleyen birçok hukukçu da mevcuttur. Yukarıda da ifade ettiğimiz üzere, Devrim Mahkemeleri ihtisas mahkemeleri niteliğindedir. Genelde her ülke kendi hukuk sistematiğini yaratma çabasında olduğu için ihtisas mahkemelerine karşı bakış açıları da farklılık göstermektedir. Örneğin Japon Anayasası, ihtisas mahkemelerini kayıtsız ve şartsız açık bir hükümle yasaklamıştır. Çin Halk Cumhuriyetinin Anayasası ise bu mahkemelerin kurulmasını hükümetin takdir yetkisine bırakmıştır. Fakat Fransa gibi Avrupa modeli demokrasilerde, ihtisas mahkemelerin meşruiyeti ancak anayasada açık bir hükmün olması ve anayasal bir kuruluş olması koşuluyla kabul edilmiştir (Tahkik, 2016: 2). İran İslam Cumhuriyeti'nin devrim mahkemeleri, anayasal bir kuruluş değildir ve dahası İran Anayasası'nda bu mahkemelerle ilgili hiçbir hükme yer verilmemiştir. İran Anayasası'nın 159. maddesine göre, “Adli davaların ve şikayetlerin resmi mercii genel görevli adli mahkemelerdir ${ }^{20}$. Adli mahkemelerin kuruluş ve görevlerini kanun belirler". Bu maddeden de anlaşıldığı gibi anayasa, bu konudaki yargılama yetkisini ancak genel görevli adli mahkemelere vermiştir. Dolayısıyla istisnai bir durum oluşturmaları sebebiyle ihtisas mahkemelerinin anayasada açık bir hükme bağlanması gereklidir. Bu iddiayı destekleyen, Anayasanın 172. ve 173. maddeleridir. Çünkü Anayasanın 172. maddesi askeri mahkemelerden, 173. maddesi ise İdari Adalet Divanı'ndan bahsetmiştir. Anayasanın 159. maddesi kural olarak hukuki ve cezai uyuşmazlıklarla ilgili yargılama yetkisini, genel görevli mahkemeler olarak adli mahkemelere vermiştir. İdari Adalet Divanı ve asker mahkemelerde olduğu gibi devrim mahkemelerinin de ihtisas mahkemesi olarak Anayasada açıkça öngörülmesi gerekirdi (Hachemi 2004: 246).

\section{YÜKSEK İDARİ MAHKEME OLARAK İDARİ ADALET DİVANI (Divan-i Adalet-i İdari)}

\section{1. İdari Adalet Divanı'nın Tarihçesi}

Tarihsel olarak İran'da idarenin yargısal denetimi ve keza İdari Adalet Divanı'nın geçmişi İran Meşrutiyet Anayasası'na (1906-1907) dayanmaktadır. 1907 tarihli İran Meşrutiyet Anayasası'nda ilk defa vatandaşlar için idari kuruluşlara karşı dilekçe hakkı öngörülmüştü. Dilekçeleri inceleme yetkisi ise Milli Meclis'e (parlamentoya) verilmişti. Meşrutiyet Anayasası'nın 32. maddesine göre, “Tüm millet fertleri kendi arzuhal, tenkit ve şikayetlerini, Meclis Arzuhal Bürosu'na verme hakkına sahiptir. Şikayet ve dilekçelerin konusu, Milli Meclis ile ilgili ise gereken cevap kendisine verilecektir. Fakat konu bakanliklar veya diğer idari kuruluşlarla ilgili ise şikayet ve dilekçeler, gereken cevabın verilmesi için bakanlıklara veya diğer idari kuruluşlara gönderilecektir". Bu düzenlemede dikkati çeken husus, böyle bir hakkın yabancılara tanınmamış olmasıdır.

İdari Adalet Divanı, ilk defa "Şurayı Devlet" adı altında 1922 yılında çıkarılan Devlet İstihdam Kanunu'nda (Kanun-e İstahdam-e Keşvari ${ }^{21}$ ) öngörüldü. Devlet İstihdam Kanunu'nun 64. maddesine göre, "İdari kuruluşlarda çalışan kamu görevlilerinin bakanlar tarafindan bu kanunu ihlal durumundaki iddialara karşı itiraz mercii Şurayı Devlet'e aittir. Fakat Şurayı Devlet'in yokluğunda bu konudaki yetkili merci Temyiz Yüksek Divanı (Divan-e Aliye-e Temyiz) olacaktır" (Didgah, 2016: 5).

1922 tarihli Borçlar Kanunu'nda (Kanuni Mesuliyet-e Medeni), ilk defa Devlet ve diğer idari kuruluşların hukuki ve mali sorumluluğu ile ilgili hükümlere de yer verilmiştir (Moosazadhe , 2010: 295) ${ }^{22}$. Borçlar

\footnotetext{
b) Krallı̆̆a karşı, aktivistleri hapse atan veya işkence yapan suçluları,

c) Hazine ve Devlet bütçesini zarara uğratan yolsuzluk gibi ekonomik suçlarl,

d) Islam Cumhuriyetine karşı her türlü terör suçları işleyenleri ve casusluk suçlarını,

e) Organize hırsızlık suçu ve her türlü yağma suçlarını,

Yargılamak ve kesin olarak karar bağlamaktır".

20 Farsçada Adliye mahkemelerine, "dadgostari” denir.

21 "Keşvar", Farsça'da "Devlet” demektir.

221922 tarihli İran Kacar Krallığı Borçlar Kanunu'nun 11 ila 13. maddeleri, idarinin mali sorumluluğu ile ilgili hükümlere yer vermiști. Bu Kanunun 11. maddesine göre, "Devlet, belediyeler ve bunlara bağlı kurum ve kuruluşlarında çalışan görevliler tarafindan görevlerini ifa esnasında kasten veya sehven zarara neden olmaları durumunda, bu zararl şahsen gidermekle sorumlu ve mükelleftirler. Fakat bu zarara neden olan idarenin araç ve gereçleri ise sorumluluk kamu görevlilerinden kalkar ve zararın giderilmesi ilgili kamu kuruluşuna aittir. Hükümet tasarrufları bu hükmün dışındadır”. (Bkz., Moosazadhe: 2010: 295).
} 
Kanunu'nun hemen ardından, aynı yıl içinde İran Milli Meclisi (Meclis-e Şuraye Melli) tarafından "Şurayı Devletin Kuruluşu Hakkında Kanun” çıkartıldı " (Didgah, 2016: 5) ${ }^{23}$. Fakat ifade etmek gerekir ki, bu kanun çıktı̆̆ 1 tarihten itibaren hiçbir zaman uygulanamadı.

1979 Devriminin hemen ardından 1980 tarihli İran İslam Cumhuriyeti Anayasası'nda “İdari Adalet Divanı” adı altında Şurayı Devlet nihayet varlığını ortaya koydu (Hachemi, 2004: 436). İdarenin yargısal denetime tabi tutulması ilkesi, İran İslam Cumhuriyeti Anayasası'nın 170. ve 173. maddelerinde öngörüldü. 1981 tarihinde ilk defa İdari Adalet Divanı ile ilgili 25 maddeden oluşan özel bir kanun meclis tarafından kabul edildi. Bir yıl sonra ise İdari Adalet Divanı yargısal faaliyetlerine resmen başlamış oldu (İdari Adalet Divanı, 2016: 1).

1979 Devriminden sonra İran İslam Cumhuriyeti Anayasası'nı hazırlayan Kurucu Meclis, bireylerin yürütme organı ve idari kuruluşlara karşı itiraz ve şikayet hakkı ile ilgili hükmü aynen Meşrutiyet Anayasası'ndan iktibas etmiştir. Yürürlükteki Anayasanın 90. maddesine göre, "Herkes, Meclisin faaliyetleri, yürütme veya yargl organlart ile ilgili şikayetlerini yazılı olarak İslami Şura Meclisine (parlamento) sunma hakkına sahiptir. İslami Şura Meclisi, yargl ve yürütme organlarını ilgilendiren şikayetleri, ilgili kuruluşlardan makul süre içerisinde gereken açılamaları talep etme yetkisine sahiptir. Kamuyu ilgilendiren konular ise ilan esasında herkese duyurulacaktır. "24

\section{2. İdari Adalet Divanın Yapısı}

\subsubsection{Genel Olarak}

İdari Adalet Divanı'nın Yargılama Usulü Kanunu'nun 2. maddesine göre, “İdari Adalet Divanı'nın yargısal teşkilatı;

- Dava daireleri (ilk derece mahkemesi olarak),

- Temyiz daireleri (teşhis daireleri),

- Divan Genel Kurulu (Heyeti Umumiye),

- Ihtisas komisyonlarından oluşur.

Divan'ın idari ve yargısal kuruluşların kurulup kaldırılması hakkında yetkili mercii Yargı Organı Başkanı'dır. Bu konuda İdari Adalet Divanı Başkanı da önerilerde bulunabilir”.

İdari Adalet Divanı, bir merkezi teşkilat olarak başkentte bulunur. Dolayısıyla ülkenin diğer illerinde hiçbir yargısal teşkilatı mevcut değildir (İADK. ${ }^{25} \mathrm{~m} .2$ ). Bu durum İdari Adalet Divanı'nı ilk ve son inceleme yargılama mercii olarak karşımıza çıkarmaktadır. Bu yönüyle İdari Adalet Divanı, bize Türk hukuk sistemindeki Askeri Yüksek İdare Mahkemesi'ni anımsatmaktadır. Fakat yargılama sürecini hızlandırma ve bu süreci kolaylaştırma maksadıyla il merkezlerinde davacı sıfatıyla gerçek ve özel hukuk tüzel kişileri yönlendirmek için bürolar açılabilir (İADK. m.6). Daha önce de ifade ettiğimiz üzere, bu konuda yetkili mercii Yargı Organı Başkanı'dır.

\subsection{2. İlk Derece Mahkemesi Olarak Dava Daireleri (Şoeb-e Bedvi)}

Divanın merkezi başkent Tahran'dır. Divan'ın idari teşkilatı ve yeni dairelerin kurulması ile ilgili yetkili mercii Yargı Organı Başkanı'dır (İADK. m.2). Her daire bir asıl ve bir yedek üyeden oluşur. Daire başkanları ile yedek üyelerinin ataması, Divan Başkanı’nın önerisi üzerine Yargı Organı Başkanı tarafından yapılır (İADK. m.2). 1. Daire başkanı aynı zamanda İdari Adalet Divanı Başkanı'dır (İADK. m.5).

Dava daireleri için gerekli görüldüğü takdirde ve ihtiyaç duyulduğu sayıda uzman kişilerden oluşan müşavir (raportör) atanabilir (İADK. m.9). Bunların da atanması, Divan Başkanı'nın önerisi üzerine Yargı Organı Başkanı tarafından yapılır. Divan'da yeni dairelerin kurulması da aynı şekilde yapılır. Dava dairelerinin kararlarına karşı temyiz yolu açıktır. İlk derece mahkemesi olarak dava dairelerin kararlarına karşı temyiz mercii, İdari Adalet Divanı temyiz daireleridir.

\footnotetext{
23 Şurayı Devletin Kuruluşu Hakkında Kanun’un 2. maddesine göre; Şurayı Devlet, bakanlıkların, belediyelerin ve bunlara ait bağlı ve ilgili kuruluşların tüm eylem ve işlemlerinin (bireysel/düzenleyici) vatandaşların hak ihlali sebebi ile kanunların uyguluk denetimi ile yetkilidir (Abdülhamd, 1997: 573; Ayrıca bkz. Alihani, 1997: 320).

24 Anayasanın 90. maddesi, Meşrutiyet Anayasasının 32. maddesine benzemektedir.

25 İdari Adalet Divanı Kanunu.
} 
Dava daireleri, idari uyuşmazlıklarla ilgili gerçek veya özel hukuk tüzel kişileri tarafından açılan davaları ilk derece mahkemesi olarak inceleme ve karara bağlamakla görevlidir. Dava dairelerinin başlıca görevlerini şunlardır (İADK. m.10):

a) Kamu kurum ve kuruluşları ile bunlara bağlı şirketler, belediyeler, sosyal güvenlik kuruluşları ve devrim kuruluşlarının $^{26}$ işlem ve eylemlerine karşı gerçek ve özel hukuk tüzel kişilerinin itiraz ve şikayetlerini inceleme,

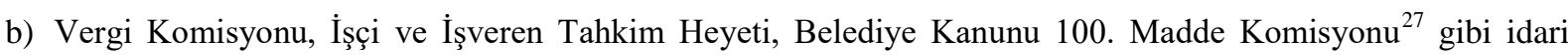
uyuşmazlıkları çözümleyen heyet ve komisyonların nihai kararlarına karşı itiraz ve şikayetlerini inceleme,

c) Tüm kamu kurum ve kuruluşlarında çalışan personelin özlük haklarının ihlalleri ile ilgili şikayetleri inceleme $\mathrm{e}^{28}$.

\subsubsection{Temyiz Daireleri (Şobe Tacdide Nazar)}

İlk derece mahkemesi olarak dava dairelerinin nihai kararlarına karşı, temyiz daireleri bulunmaktadır. Bu daireler bir başkan ve iki üyeden oluşur. Temyiz daireleri en az iki üye ile toplanır ve oyçokluğu ile karar verir. Temyiz dairesi iki kişinin toplanmasıyla karar verirse ve iki karar da çelişirse, Divan Başkanı oylama için üçüncü kişi olarak diğer daire üyelerinden birini görevlendirir (İADK. m.3).

İlk derece mahkemesi olarak dava dairelerinde görülen davalarda verilen kararlara karşı davanın tarafları, taraf avukatları ve kanuni vekaleti olanlar temyiz yoluna başvurabilir. Temyiz süresi kararın tebliğinden itibaren İran'da ikamet edenler için yirmi gün, yurtdışında ikamet edenler için ise iki aydır (İADK. m.65).

Temyiz dairesi, temyiz talebinde bulunan kişi veya kişilerin isteklerini haklı bulmazsa ilk derece mahkemesi olarak davaya bakan divan dairesinin kararını onar. Aksi halde kararı bozup yeniden görüşülmesi için ilgili daireye gönderir (İADK. m.71).

\subsubsection{Divan Genel Kurulu (Heyet-e Umumiye-ye Divan)}

Divan Genel Kurulu, başta Divan Başkanı olmak üzere ilk derece dava daireleri ile temyiz dava dairelerinin başkan ve üyelerinden oluşur. Divan Başkanı'nın yokluğunda başkan yardımcısı kurula başkanlık eder. Divan Genel Kurulu'nun toplantı yetersayısı üçte iki olup, karar yetersayısı ise salt çoğunluktur (İADK. m.9/1). Divan Başkanı'nın kararıyla ihtisas konularında danışmanlık için raportörler de kurul toplantılarına katılırlar. Fakat raportörler oy kullanma hakkına sahip değildirler (İADK. m.9/2).

Divan Genel Kurulu'nun görev ve yetkileri aşağıdaki şekilde sıralanabilir (İADK. m.6, m.12):

a) Devlet (merkezi teşkilat) ve diğer kamu tüzel kişilerinin tüzük, yönetmelik gibi düzenleyici işlemlerine karşı açılacak davalara bakmak,

b) Dava daireleri arasında çıkan görev uyuşmazlıklarını nihai inceleme mercii olarak karara bağlamak,

c) Dava daireleri tarafından konusu ve sebebi aynı olan davalarla ilgili hüküm uyuşmazlığı durumunda içtihadı birleştirme kararları almak.

\subsection{5. İhtisas Komisyonları (Heyetha-ye Tahassosi)}

İhtisas komisyonları, en az on beş üyeden oluşur. Divan Başkanı, üyelerinin tamamını Divan yargıçları arasından atar (İADK. m.84/1). Komisyonların kuruluşu ve üye sayısının belirleme yetkisi Divan Başkanı'na aittir (İADK. m.84/4). Komisyon üyelerinin görev süresi bir yıldır. Komisyonlarda bir başkan, başkan yardımcısı, genel sekreter ve özel kalem müdürü bulunur (DİKY ${ }^{29}$. m.4). Tüm ihtisas komisyonlarında toplantı yetersayısı üçte ikidir (İADK. m.84/1).

\footnotetext{
261979 Devriminin hemen ardından "Devrim Kuruluşları” adı altında bazı önemli kuruluşlar tesis edildi. Günümüzde bu kuruluşlardan bazıları (Devrim Muhafızları, İslami Kalkınma gibi) bakanlık düzeyinde varlıklarını sürdürmektedir. Aslında bu kuruluşlar, Devrimin ideallerini gerçekleştirme amacını gütmektedir.

2717 fikradan oluşan İran Belediye Kanunu'nun 100. maddesi, mesken ve ticari taşınmazların yapı ruhsat ve kullanma izni ile ilgili konuları düzenlemektedir. $\mathrm{Bu}$ maddede ayrıca bu konulardaki izin ve ruhsatlarla ilgili uyuşmazlıkların çözüm mercii olan "100. Madde Komisyonu'nun olușumu ve görev yetkilerinden bahsedilmektedir.

28 Hakim, savcı ve diğer yargı mensuplarının özlük işleri de bu kapsamdadır.

29 Divan Genel Kurulu ve İhtisas Komisyonlarının Faaliyet Usulüyle İlgili Yönetmelik.
} 
İhtisas komisyonları Divan Genel Kurulu'nun ön inceleme bürosu gibidir. Divan Genel Kurulu'nun görev alanına giren konular önce ihtisas komisyonlarına gönderilir. İhtisas komisyonları, Divan Genel Kurulu'nun görev alanına giren davalarla iki tür karar verme yetkisine sahiptir. İlgili komisyon davadaki talebi haklı bulmazsa davayı reddeder, talebi haklı bulursa konuyu kesin hükme bağlaması için Divan Genel Kurulu'na gönderir. Birinci durumda karar yetersayısı komisyonlarda dörtte üçtür. İkinci durumda ise salt çoğunluktur. İhtisas komisyonları, hukuka aykırılık durumunu gördüğü takdirde aykırılık gerekçeleri ile birlikte dava dosyasını Divan Genel Kurulu'na gönderir. Örneğin İhtisas komisyonu, Devlet ve diğer kamu kurum ve kuruluşların düzenleyici işlemlerine karşı açılan davaları haklı bulup, bu işlemleri hukuka aykırı gördüğü takdirde aykırılık gerekçeleri ile birlikte dava dosyasını Divan Genel Kurulu'na gönderir. Fakat bahsi geçen davalarda ihtisas komisyon üyelerinin dörtte üçünün kararı davanın reddi yönündeyse, komisyon ilgili davanın reddine karar verir ve dava dosyasını Divan Genel Kuruluna göndermez. Komisyonların bu tür kararlarına karşı İdari Adalet Divan Başkanı ve en az 10 Divan yargıcı 20 gün içinde Divan Genel Kurulu'na itiraz edebilir (İADK. m.84/3). İhtisas komisyonları esas itibariyle Türk yargı sistemindeki Yargıtay ve Danıştay'da bulunan tetkik hakimlerine benzemektedirler. Çünkü bu komisyonlar esas itibariyle Divan Genel Kurulu’na danışmanlık yaparlar. Ancak bu komisyonlar, Türk yargı sistemindeki tetkik hakimlerinden farklı olarak sadece danışmanlık görevi yapmayıp, davayı reddetme gibi önemli bir yetkiye de sahiptirler.

\subsection{6. İcra Birimleri (Vahede İcra-ye Ahkam)}

İlk derece mahkemesi olarak kesinleşmiş kararlar ile temyiz dairelerinin kesin kararlarının uygulanması maksadıyla Divan Başkanı veya başkan yardımcılarının başkanlığında ve savcılardan oluşan icra birimleri öngörülmüştür (İADK. m.9). İlk derece mahkemesi olarak kesinleşmiş kararlar ile temyiz dairelerinin kesin kararları ilgili idari kuruluşlar tarafından ivedilikle yerine getirilmelidir (İADK. m.107). Bu kararların ilgili idari kuruluşlar tarafindan uygulama süresi en fazla otuz gündür (İADK. m.108). Öngörülen süre içinde bu kararların idari kuruluşlar tarafından uygulanıp uygulanmamasını takip etme icra birimlerinin görevleri arasında yer almaktadır. Kesin olan veya kesinleşmiş kararların öngörülen süre içinde ilgili kamu görevlisi tarafından uygulanmaması, "kişisel kusur" olarak kabul edilmektedir. Bu durumda, ilgili kamu görevlisi, Divan Başkanı'nın veya ilgili dava dairesinin kararı üzerine geçici olarak görevden uzaklaştırılarak hakkında Divan'da konuyla ilgili yargılama süreci başlatılır. Yargılama sonucunda kusurlu bulunan kamu görevlisi oluşan maddi ve manevi zararı şahsen karşılamakla sorumludur (İADK. m.109). Özel hukuk kurallarından farklı olarak, Türk idare hukukunda "kusur" kavramı nesnel ve objektif niteliktedir. Dolayısıyla kamu görevlerinin hizmet içi kişisel kusur durumlarında bile zarar görenler, kamu görevlilerine karşı değil, idareye karşı tam yargı davası açarlar. Kamu görevlileri tarafından yargı kararlarını uygulanmaması geleneksel hizmet içi kişisel kusur türlerinden bir olarak kabul edilmektedir. Fakat İran İslam Cumhuriyeti idare hukukunda kamu görevlileri tarafindan yargı kararlarının uygulanmaması durumunda, idareye değil ilgili kamu görevlisine karşı tazminat davası açılmaktadır.

\section{SONUÇ}

34 yıllık bir geçmişe sahip olan İdari Adalet Divanı, nicelik olarak gelişmektedir. Fakat Devrim öncesi süreci göz önüne aldığımızda, özellikle rakipleri sayılan devrimin diğer ortaklarının tasfiyesi ve "Vilayeti Fakih" doktrini esasında İslam Cumhuriyetinin gelişiminde İran Devrimi kendine has yargı sistematiğini oluşturma çabasında olmuştur. Bu esasta yargı, hukukun genel ilkelerini sağlamaktan ziyade devrim sonrası tasfiye aracı olarak kullanılmıştır.

İran'ın yargı sistemi ile ilgili eleştirilerin temelinde diğer konularda olduğu gibi "Tanrı Devleti” (teokratik devlet) anlayışı yatmaktadır. Bir başka deyişle, Dini Lider'in (Vilayet-i Fakih) devletin üç organında da sınırsız yetkilere sahip olması dolaysıyla yargı bağımsızlığı ilkesi sorununu da bu kapsamda değerlendirmek gerekir. Fakat bu sorunların ötesinde daha yapıcı ve konuyla ilgili somut ve olumlu bir eleştiri tam anlamıla bir idari yargı sisteminin olmamasıdır.

İran'da bazı istisnai durumlar hariç idari uyuşmazlıklara karşı itiraz mercii yürütme bünyesinde yer alan komisyonlar veya heyetlerdir. İdari Adalet Divanı ise bu süreçten sonra ilk ve son inceleme mercii olarak görev yapmaktadır. Bu komisyon veya heyetler yerine iller veya vilayetlerde ilk derece ve istinaf mahkemeleri kurulması gerekmektedir. 
İdari yargı idarenin yargısı anlamına gelmeyip, tam tersine iç hukuktaki insan hakları mahkemesi niteliğindedir. Modern ülkelerde yönetimde bulunan görevlilerin sık sık idari yargıdan şikayetçi oldukları dikkate alındığında, idari yargı mahkemelerinin idarenin yanında olmayıp tarafsız oldukları görülmektedir (Yıldırım, 2008: 10).

İdari Adalet Divanı’nın Türk Danıştay’ı gibi bir yüksek mahkeme olarak sadece temyiz davalarının son inceleme mercii görev yapması daha uygun olurdu. İdari uyuşmazlıkları çözme yetkisi sadece İdari Adalet Divanı'na ait değildir. İran'da bu konuda yargı organı dışında yer alan dahası yürütmeye bağlı onlarca komisyon, heyet gibi yetkili merciiler de bulunmaktadır. Bu mercilerin yapısı ve oluşumu dikkate alındığında, bunların mahkeme vasfina ve özelliklerine sahip olmadığı görülmektedir. Bu komisyonlar ve heyetlerin üyeleri genellikle bakanlar ve ya diğer kamu kuruluşları tarafindan atanmaktadır.

\section{KAYNAKÇA}

Abdülhamd, A. (1997). Huquq-e Edariye İran (İran'ın İdari Hukuku), Tus Yayınları, Tahran.

Alihani, M. (1997). Sahtar-i İdari İran (İran’nın İdari Yapısı), Lale Yayınları, Tahran.

Askeri Mahkemeler Yargilama Usul Kanunu, İran Resmi Gazetesi Web Sitesi, http://rooznamehrasmi.ir/Laws/ShowLaw.aspx?Code=2256, Erişim: 13.9.2016.

Birinci ve İkinci Derece Ceza Mahkemeleri ve Yüce Divan'ın Kuruluşu Hakkında Kanun, İran Adliye Teşkilatı Resmi Web Sitesi, http://www.ghavanin.ir/detail.asp?id=11616, Erişim: 16.9.2016.

Çağlayan, R. (2015). İdari Yargılama Hukuku, Seçkin Yayınevi, 7. Baskı, Ankara.

Devrim Mahkemeleri ve Savcılıkları Hakkında Tüzük, İran İslam Cumhuriyeti Parlamentosu'nun Resmi Web Sitesi, http://rc.majlis.ir/fa/law/show/99447, Erişim: 17.9.2016.

Didgah, Nim Negahi Be Tarikhçeye Qavanin-e Dadresi dar İran (İran'ın Yargılama Usul Kanunlarının Tarihsel Gelişimi), http://www.farsnews.com/printable.php?nn=13931128001734, Erişim: 3.8.2016.

Divan Genel Kurulu ve İhtisas Komisyonlarının Faaliyet Usulüyle İlgili Yönetmelik, İran Resmi Gazetesi Web Sitesi, http://rooznamehrasmi.ir/Laws/ShowLaw.aspx?Code=4729, Erişim: 15.9.2016.

Ergen, C. (2008). İdari Yargılama Usulü Kanunu Şerhi, Seçkin Yayınevi, Ankara.

Genel Görevli Adli Mahkemeleri ile Devrim Mahkemelerinin Yargılama Usulü Kanunu, İran İslam Cumhuriyeti Parlamentosu'nun Resmi Web Sitesi, http://rc.majlis.ir/fa/law/show/90416, Erişim: 17.9.2016.

Gözler, K. ve Kaplan, G. (2014). İdare Hukuku Dersleri, Ekin Yayınevi, 15. Baskı, Bursa.

Hachemi, M. (2004). Huquq-e Esas-i Cumhuri-e Eslami-e İran (İran İslam Cumhuriyeti Anayasa Hukuku), C. 2 , Mizan Yayınları, Tahran.

Hukuk Mahkemelerinin Kuruluşu Hakkında Kanun, İran İslam Cumhuriyeti Parlamentosu'nun Resmi Web Sitesi, http://rc.majlis.ir/fa/law/show/93837, Erişim: 17.9.2016.

Hukuk ve Ceza Mahkemeleri ile Devrim Mahkemelerin Kuruluşu Hakkında Kanun, İran Adalet Bakanlığı'nın Resmi Web Sitesi, http://www.dastour.ir/brows/?lid=152297, Erişim: 15.8.2016.

İdari Adalet Divanı Kanunu, İdari Adalet Divanı, Resmi Web Sitesi, http://www.divanedalat.ir/show.php?page=law, Erişim: 5.8.2016.

İdari Adalet Divanı, Resmi Web Sitesi, Divan-e Adalet-e Edari Dar Yek Negah (İdari Adalet Divanı'na Kısa Bir Bakış), http://www.divan-edalat.ir/show.php?page=about, Erişim: 5.8.2016.

İran Ceza Muhakemeleri Usul Kanunu, http://www.rrk.ir/Laws/ShowLaw.aspx?Code=12989, Erişim: 12.9.2016.

İran İslam Cumhuriyeti'nin Anayasası, İdari Adalet Divanı, Resmi Web Sitesi, http://www.divanedalat.ir/show.php?page=base, Erişim: 5.8.2016.

Kalabalık, H. (2015). İdari Yargılama Usulü Hukuku, Sayram Yayınları, Konya. 
Mohammadi M. (2016). Dadegah-e Vije Ruhaniyet, Felsefe-e Vucudi, Sakhtar, Amalkard (Ruhanilerin İhtisas Mahkemesi, Tarihçe, Yapısı ve İşleyişi), Merkaz-e Esnad-e Hukuk-e Beşer-e İran (İran'ın İnsan Haklar1 Belgeleri Merkezi), http://www.iranhrdc.org/files.php?force\&file=/Special_Court_for the_ClergyPersian_560756249.pdf, Erişim: 8.8.2016.

Moosazadhe, R. (2010). Huqe Edari İran (İdare Hukuku), Nashre Mizan (Mizan Yayınları), 8. Baskı, Tahran.

Mumcu, U. (2016), İstiklal Mahkemeleri, Cumhuriyet Gazetesi, 11.11.1992, http://www.tekadamdevrimi.com/index.php?option=com_content $\&$ view=article \&id=286\&Itemid=51, Erişim: 5.8.2016.

Ruhaniler İhtisas Mahkemesi Savcılığı ve Muhakeme Usul Yönetmeliği, http://irandataportal.syr.edu/wpcontent/uploads/scc-statute.pdf, Erişim: 10.9.2016.

Tahkik İsmail; Meşruiyet-i Dadegahha-ye Enqelab (Devrim Mahkemelerinin Meşruiyeti), http://www.panijoon.blogfa.com/, Erişim: 5.8.2016.

Yargıçların Disiplin Mahkemesi Kanunu, İran Resmi Gazetesi Web Sitesi, http://www.rooznamehrasmi.ir/Laws/ShowLaw.aspx?Code=933, Erişim: 13.9.2016.

Yıldırım, T. (2008). İdari Yargı, Beta Yayınları, İstanbul.

Zebhi M. (2016). Karkerd-e Dadegah-haye Tacdid-e Nazar (İl Mahkemelerinin İşleyişi, Görev ve Yetkileri), http://www.zebhi.ir/print.php?ToDo=ShowArticles\&AID=51923, Erişim: 3.8.2016. 